\title{
The Narrow Road to Exoneration - the Incidence, Characteristics and Outcomes of Wrongful Conviction Claims in Sweden over a One-Year Period
}

\author{
SARA HELLQVIST ${ }^{*}$
}

\section{Introduction}

\subsection{Wrongful Convictions and the Road to Exoneration}

Wrongful convictions pose a great threat to democratic societies built on the rule of law. ${ }^{1}$ Although the frequency of wrongful convictions varies across legal systems, the issue of wrongful convictions is a global one and different countries have devoted varying degrees of effort to addressing it. ${ }^{2}$ Overall, awareness about different types of miscarriage of justice has grown dramatically in Anglo-American countries, to the extent that these

* Sara Hellqvist, PhD Candidate, the Department of Criminology, Stockholm University.

1 Huff et al., Guilty until proved innocent: Wrongful conviction and public policy, 32 Crime \& Delinquency (1986) pp. 518-544.

2 Killias, Errors occur everywhere - but not at the same frequency: The role of procedural systems in wrongful convictions in Wrongful Convictions \& Miscarriages of Justice, eds. Huff and Killias (Routledge 2013) pp. 61-76. 
developments have been referred to as a revolution. ${ }^{3}$ From a criminological point of view, it is interesting to note the societal conditions surrounding these advances in the scholarship and also the impact they have had in a broader context. For instance, the increasing emergence of public distrust in the criminal justice system, as a result of high-profile DNA exoneration cases, has been suggested to be one of the reasons for the shift away from a punitive crime policy approach in the United States. ${ }^{4}$ Today, Anglo-American research on wrongful conviction is considered to have had extensive impact on policy reforms. As Radelet puts it:

Once we realize that we occasionally convict defendants who are totally innocent, we can use that realization as a window through which we can see all sorts of errors - or potential errors - that can be made ... Perhaps the most important effect of the growing attention to wrongful convictions is that it opens (or reopens) the door for research and debate about other imperfections in the criminal justice system. ${ }^{5}$

However, 'wrongful convictions' is a complex concept and to look only at known exonerations is not sufficient, as some cases may be more likely to be detected than others. ${ }^{6}$ One way of investigating the phenomenon of wrongful convictions is therefore to study the road to exoneration. In modern western societies, offenders who consider themselves wrongfully convicted following a final verdict are able to file an application for review, i.e. to request a re-examination of their convictions. ${ }^{7}$ If the application is approved and the criminal case is reopened ${ }^{8}$, it is possible for the convicted person to be awarded a

3 Findley, Innocence found: The new revolution in American Criminal Justice, No. 1263 Legal Studies Research Paper Series (2014); Leo, The criminology of wrongful convictions: A decade later, 33 Journal of Contemporary Criminal Justice (2017) pp. 82-106; Norris, Framing DNA: Social movement theory and the foundations of the innocence movement, 33 Journal of Contemporary Justice (2017) pp. 26-42.

4 Gould, The innocence commission. Preventing wrongful convictions and restoring the criminal justice system (NYU Press 2008); Simon, Foreword in Naughton, Rethinking miscarriages of justice: Beyond the tip of the iceberg (Palgrave Macmillan 2012).

5 Radelet, Foreword in Wrongful Convictions \& Miscarriages of Justice, eds. Huff and Killias (Routledge 2013) pp. xv-xviii.

6 Gross, How many false convictions are there? How many exonerations are there? in Wrongful Convictions \& Miscarriages of Justice, eds. Huff and Killias (Routledge 2013) pp. 45-59.

7 Dongois, Wrongful conviction in France. The limits of 'pourvoi en revision' in Wrongful Conviction. International Perspectives on Miscarriages of Justice, eds. Huff and Killias (Temple University Press 2008) pp. 249-262.

8 In this article, the term 'reopened' is used as a translation of the Swedish word 'resning' and the Norwegian word 'gjenopptakelse' (see for example Stridbeck and Magnussen 2011-2012; and The Norwegian Criminal Cases Review Commission, Annual report for 2016). 'Reopened' should be regarded as a synonym to an 'approved application'. That is, when an application for review has been approved, the criminal case is to be considered as reopened. 
more lenient sentence or to be exonerated. In some respects, the post-conviction review process can be regarded as lying at the heart of the wrongful conviction issue, since this is where alleged miscarriages of justice are either acknowledged as such or rejected, at least in a legalistic sense. ${ }^{9}$ Given that known cases of exoneration are probably not representative of wrongful convictions in general, and instead is an outcome of the resources that are assigned to a case, ${ }^{10}$ this article focuses on the post-conviction review procedure, in which the conditions and requirements necessary for wrongful conviction claimants to have their criminal cases reopened are examined.

Despite relatively lenient sentences, Norway has recognised wrongful convictions as a problem that needs to be addressed. The Norwegian post-conviction review process is characterised by thorough transparency and some of the measures taken to prevent and correct wrongful convictions can in some respects be considered to lie at the forefront of policy reforms. ${ }^{11}$ This is not the case in Sweden, however. Wrongful convictions, their incidence, causes and consequences, are in many aspects viewed as a non-issue. ${ }^{12}$ This is illustrated quite explicitly by the absence of Swedish statistics on the number of convicted individuals who claim to have been wrongfully convicted, on their reasons for these claims and on how these claims are dealt with by the courts. If the post-conviction review process is to be recognised as serving an important gatekeeping function within the criminal justice apparatus, opening or closing the door on whether a verdict may be acknowledged as wrongful, there is an urgent need for more transparency in this part of the criminal justice system.

As is the case in most countries, Sweden has had a number of high-profile wrongful conviction cases in which people have been imprisoned for years before having their convictions overturned. The most recent example of such an extreme high-profile case relates to a man whose fourth application to have his conviction reviewed was approved and who was exonerated in June 2017 after serving more than 12 years in prison for murder. ${ }^{13}$ These exoneration cases have produced some public concern and debate about the implementation of further legal safeguards, such as the establishment of an independent

9 Naughton, Redefining miscarriages of justice. A revived human-rights approach to unearth subjugated discourses of wrongful criminal conviction, 45 British Journal of Criminology (2005) pp. 165-182.

10 Curran and Noone, Access to justice: A new approach using human rights standards, 15 International Journal of the Legal Profession (2008) pp. 195-229.

11 Stridbeck and Magnussen, Opening potentially wrongful convictions: Look to Norway, 58 Criminal Law Quarterly (2011-2012) pp. 267-283; Stridbeck and Magnussen, Prevention of wrongful convictions: Norwegian legal safeguards and the Criminal Cases Review Commission, 80 University of Cincinnati Law Review (2013) pp. 1372-1390.

12 Träskman, Rätten till riktig resning: en fråga försummad av forskningen?, 3 Nordisk Tidsskrift for Kriminalvidenskab (2005) pp. 249-270.

13 The Supreme Court, case number Ö 5257-15. Decision announced 2016-12-29; Övre Norrland court of appeal, case number B 1138-16. Verdict announced 2017-06-15. 
commission as in Norway. It is noteworthy, however, that there is no statistical information on this particular area of the criminal justice system in Sweden. As a consequence, the discussions and the proposals that are presented lack any empirical foundation.

It is important to emphasise that wrongful convictions are often a result of the failure of legal safeguards. The Nordic justice systems have implemented a number of safeguards against wrongful conviction, as for instance the provision of defence attorneys at public expense and to not allow plea bargains, and they generally maintain high legislative standards and a high standard of proof in relation to the question of guilt. ${ }^{14}$ In addition, the Nordic countries are small, both in terms of overall population and their prison populations, and they have fairly liberal sentencing policies. However, these factors are not a satisfactory explanation for treating wrongful conviction as a non-issue in Sweden when the progressive work that has been conducted in Norway is considered. At the same time, before a conclusion can be reached on whether the path adopted in Norway is also appropriate for Sweden, it is necessary to develop an empirical foundation from which to proceed.

\subsection{Wrongful Conviction Claims and the Final Legal Safeguard}

As regards the ways in which the post-conviction review process can be structured, the United States has been described as lagging behind Canada and the United Kingdom. ${ }^{15}$ One could also add Norway to the list of countries taking a lead, following the introduction of a partly similar architecture to those found in Canada, England and Scotland. ${ }^{16}$ These countries have all established criminal cases review commissions or review groups that review alleged miscarriages of justice once other traditional legal avenues have been exhausted. They have the mandate to carry out further investigation of a case and to recommend or, as is the case in Norway, to instruct courts to reopen specific criminal cases. In Norway, the applicants are also offered assistance and guidance by commission advisors in order to complete a satisfactory application. ${ }^{17}$ The Canadian review group is, however, not independent in the same way as the other commissions because wrongful conviction claims are adjudicated by a government minister, but with the assistance of the review group. ${ }^{18}$ The commissions were partly introduced in response to a decrease

$14 \quad$ See Stridbeck and Magnussen 2011-2012 pp. 267-283; see Stridbeck and Magnussen 2013 pp. 1372-1390.

15 See Gould 2008.

16 See Stridbeck and Magnussen 2011-2012 pp. 267-283; Stridbeck and Magnussen 2013 pp. 13721390.

17 The Norwegian Criminal Cases Review Commission, Annual report for 2016 (2017).

18 Leverick, Campbell and Callander, Post-conviction review: Questions of innocence, independence and necessity, 47 Stetson Law Review (2017) pp. 1-29. 
in public confidence in the criminal justice system. ${ }^{19}$ At the time, the mass media had highlighted cases in which applications by exonerees had repeatedly been declined before approval was finally granted to reopen their cases. Critics were questioning the objectivity and independence of the courts, and argued that the courts lacked experience and competence in handling wrongful conviction claims. ${ }^{20}$ While many consider the commissions a welcome addition to the traditional criminal justice system, others question the foundations on which they were built, arguing that the commissions are not doing the job they were intended to do, that they are too loyal towards the court system and that they constitute little more than window dressing in an attempt to restore legitimacy and re-establish public trust in the criminal justice system. ${ }^{21}$

Limiting the focus to the Nordic setting, the Danish model is arranged slightly differently to the Swedish and Norwegian systems. ${ }^{22}$ This unit is a part of the Danish Supreme Court and is not independent in the Norwegian sense. It is, however, dedicated to handling applications of this kind, along with other complaints regarding judicial decisions and procedures. Finland, on the other hand, has a post-conviction review process similar to that found in Sweden. ${ }^{23}$ The Swedish review procedure is administered within the court system. ${ }^{24}$ The applicant is normally the convicted person, but a prosecutor and the Prosecutor General can also file an application for review on behalf of the convicted person. This mostly happens in rare circumstances when a systematic error of judgment in the criminal proceeding has been detected. The basic structure of the Swedish post-conviction review procedure is such that when an applicant files for review and the previous judgment was issued by one of the country's 48 district courts, the application is assessed and the decision made by one of the six appeal courts. If the previous judgment was issued

19 Nobles and Schiff, The criminal cases review commissions: Reporting success? 64 The Modern Law Review (2001) pp. 280-299; Huff, Foreword by C. Ronald Huff in The Criminal Cases Review Commission. Hope for the Innocent? ed. Naughton (Palgrave Macmillan 2011) pp. xvi-xvii; see Stridbeck and Magnussen 2013 pp. 1372-1390.

$20 \quad$ See Nobles and Schiff 2001 pp. 280-299; See Stridbeck \& Magnussen 2011-2012 pp. 267-283.

21 Naughton, Introduction in The Criminal Cases Review Commission. Hope for the Innocent? ed. Naughton (Palgrave Macmillan 2011) pp. 1-16; Naughton, The innocent and the criminal justice system: A sociological analysis of miscarriages of justice (Palgrave Macmillan 2013; see Nobles and Schiff 2001 pp. 280-299; Nobles and Schiff, Understanding miscarriages of justice: Law, the media, and the inevitability of crisis (Oxford University Press 2002); see Stridbeck and Magnussen 2011-2012 pp.267-283; Zander, Foreword by Michael Zander in The Criminal Cases Review Commission. Hope for the Innocent? ed. Naughton (Palgrave Macmillan 2011) pp. xviii$\mathrm{xx}$.

22 The Special Court of Indictment and Revision (2017, September 22). Retrieved from https:// www.domstol.dk/densaerligeklageret/The\%20Special\%20Court\%20of\%20Indictment $\% 20$ and\%20Revision/Pages/default.aspx (last accessed 31 January 2018).

23 Johnson, Post-trial judicial review of criminal convictions: A comparative study of the United States and Finland, 64 Maine Law Review (2012) pp. 425-476.

24 Ekelöf and Edelstam, Rättsmedlen 12:e upplagan (Iustus förlag 2008). 
by one of the appeal courts or the Supreme Court, the decision is made by the Supreme Court. If the application is approved, the charges can either be immediately dismissed, or the reopened case will be referred back to the lower court for retrial. Re-examination of a conviction constitutes an extraordinary remedy, which means that applications are only to be approved if extraordinary conditions are considered to be present. ${ }^{25}$ Sweden is one of a small number of countries which has a procedure that allows for the retrial of defendants for offences for which they have previously been acquitted, although this procedure is strictly regulated. ${ }^{26}$

Norway is the only Nordic country that provides detailed official statistics of the operation of the post-conviction review process. For instance, in 2015 the commission reviewed 144 applications on their merits and reopened 40 of them (which represent a $28 \%$ approval rate). ${ }^{27}$ When considering these figures, it should be noted that Norway accepts evidence of legal insanity as grounds for reopening a case, which is not the case in Sweden. ${ }^{28}$ In 2015, 30 cases were reopened due to doubt about the convicted person's criminal liability as a result of possible insanity and where the proceedings might have been invalid. Thus, insanity is a key reason for reopening a criminal case in Norway. When these cases are excluded, the approval rate decreases to $7 \%$. As has already been noted, the number and characteristics of the criminal cases passing through the Swedish post-conviction review process is unknown. ${ }^{29}$ In 2004, a committee was appointed by the Prosecutor General to examine the criminal justice system with the purpose of identifying potential flaws. The committee's report stated that the quality of the judicial process was 'despite everything, not that bad', ${ }^{30}$ that the post-conviction review process was considered to be well-functioning and that the proportion of reopened cases was at a reasonable level. However, the definition of 'reasonable' was not clarified, nor was there any clarification as to in what ways, and for whom, the post-conviction review process was considered to be well-functioning. Furthermore, these conclusions were based only

25 Code of Judicial Procedure, chapter 58 section 2.

$26 \quad$ Code of Judicial Procedure, chapter 58 section 3.

27 The Norwegian Criminal Cases Review Commission, Annual report for 2015 (2015).

28 Grøndahl and Stridbeck, When insanity has gone undiscovered by the courts: The practice of the Norwegian Criminal Cases Review Commission in cases of doubts about insanity, 26 Criminal Behaviour and Mental Health (2016) pp. 212-224.

29 Between 1950 and 1988, statistics were compiled by the Supreme Court, which at that time made decisions in relation to all applications. During this period, 4-6 cases were reopened each year. When the appeal courts were tasked with making decisions in relation to applications regarding judgments issued by the district courts in the early 1990s, the numbers of reopened cases were no longer reported (Office of the Chancellor of Justice, 2006).

30 Author's translation of 'trots allt inte är så illa ställt med kvaliteten' (Office of the Prosecutor General, Hållbara domslut - en förtroendefråga för rättsväsendet (Åströms tryckeri 2004) p. 6. [...] 'despite everything' refers to the notion made by the report's author that the media often only directs attention to the flaws. 
on informal meetings with criminal justice professionals. A more intense debate was initiated as a result of two reports published by the Office of the Chancellor of Justice. ${ }^{31}$ The reports called for changes, among other things noting a need for systematic information about wrongful conviction claims and exonerations. The reports resulted in a number of media headlines, but there was no other significant response from the government. With the exception of these official reports, other contributions to the field of wrongful convictions in Sweden have for the most part been based on a strictly legal perspective. ${ }^{32}$ Although they provide highly valuable insights, it is also necessary to apply empirical and theoretical perspectives from the social sciences. ${ }^{33}$

\subsection{Aims of the Study}

Against this background, the overall aim of the present article is to provide an empirical foundation for an informed discussion of wrongful convictions. More specifically, the article examines wrongful conviction claims and the judicial outcomes of these claims. This is achieved by describing the incidence, characteristics and outcomes of filed applications that have passed through the post-conviction review process over a one-year period. The findings are interpreted in the light of contemporary international wrongful conviction research and are discussed in relation to the view that the operation of the post-conviction process may be understood as a means by which the legal system may preserve its legitimacy. ${ }^{34}$ The article also discusses why there is a need for more transparency in this particular part of the criminal justice system in Sweden.

31 Office of the Chancellor of Justice, Felaktigt dömda, Rapport från JK:s rättssäkerhetsprojekt (Elanders Gotab 2006); Office of the Chancellor of Justice, Felaktigt dömda, Rapport från JK:s andra rättssäkerhetsprojekt (Elanders Gotab 2009).

32 The most extensive work is a doctoral thesis from 1959, Cars, Om resning i brottmål (Håkan Ohlssons boktryckeri 1959). Besides the present article, which is a part of an ongoing doctoral thesis, there is another doctoral candidate who is examining the Swedish post-conviction review process and wrongful convictions. These studies are not yet published, but some findings can be found online (see Lidén, Felaktiga brottmålsdomar är rättsstatens Akilleshäl - en genomgång av 2078 resningsansökningar (31 October 2016) Retrieved from http://www.dagensjuridik. se/2016/10/analys-kronika-moa-liden-1 (last accessed 31 January 2018).

33 Sandefur, Access to justice: Classical approaches and new directions in Access to Justice, ed. Sandefur (Emerald Group Publishing Limited 2015) pp. ix-xvii.

$34 \quad$ See Stridbeck and Magnussen 2013 pp. 1372-1390. 


\subsection{A Note on Terminology}

The wrongful convictions literature has been described as a conceptual muddle. ${ }^{35} \mathrm{~A}$ debated topic within the scholarship is concerned with the distinction between 'actual innocence' and 'legal innocence. ${ }^{36}$ However, a thoroughly definitional refinement of 'innocence' falls outside the objectives of this article. ${ }^{37}$ As explained in the introduction section, this article focuses on the preceding phase; wrongful conviction claims and decisions on these claims, and not whether a wrongful conviction claimant is innocent. Still, wrongful conviction claims in the examined applications are coded into two categories that need clarification.

For the purpose of the current analysis and in order to grasp the characteristics of the material, the wrongful conviction claims are categorised either as claims that are concerned with issues of fact or as claims that are concerned with issues of law. The first category refers to applications that are challenging a conviction, which is the type of claims that the Anglo-American wrongful conviction scholarship normally covers. This category involves situations were an applicant claims that the convicted person is not the perpetrator, that the convicted person should be regarded as innocent even though they committed the act (for example self-defence cases or that the act was an accident) or that no criminal offence has occurred at all. The second category has to do with legal technicalities or a change in an issue of law, for example when the applicant acknowledges that the convicted person is criminal liable but requests a more lenient sentence or when a legal circumstance has been interpreted in an incorrect way by the court. There is, however, a blurred line between 'issues of fact' and 'issues of law' in some instances, as in self-defence cases where the convicted person actually committed the act but claims that it was without criminal intent and that he or she should not be punished for it. ${ }^{38}$ Furthermore, by including the issues of law cases in the analysis of wrongful convictions, what is being discussed here is broader than in the Anglo-American literature. But since the Swedish post-conviction review process has not been covered in detail before, these cases are important to include in order to provide a transparent overview of the entire process.

35 See Naughton 2013.

36 Stratton, Wrongfully convicting the innocent: A state crime? Criminology (2014) pp.1-17.

37 For diverse and contested definitions, see for example Huff, Wrongful conviction and public policy: The American Society of Criminology 2001 presidential address in, 40 Criminology (2002) pp. 1-18; see Stratton 2014 pp. 1-17.

38 For a discussion about differences and relationships between similar concepts, see Lindell, Matters of fact and matters of law: A study of borderlines, differences and relationships between fact and law (Iustus 1987). 


\section{Method}

\subsection{Material}

The analysis is based on official legal documents. Specifically, the empirical sources comprise applications for review filed in accordance with the Code of Judicial Procedure chapter 58, sections 2-3. In total, the material includes 383 applications that were decided in 2015 by either the Supreme Court or one of Sweden's six appeal courts. The courts were asked to provide all case files that contained applications for review in criminal cases that were concluded by means of a decision made in 2015. A group of atypical cases was excluded, as explained below. The exclusion of these cases meant that a total of 216 applications were analysed. Because of the descriptive nature of this study, the characteristics of the case files are presented in the results section. Evidently, to only include one year in the analysis is a limitation, but as a result of data collection difficulties it was not possible to extend the observation period. This is an additional indication of the lack of transparency in this part of the criminal justice system and is considered in detail in the discussion section.

\subsubsection{Excluded Cases}

A large proportion of the applications, 167 out of 383, related to tax offences and false accounting offences, which were excluded from the analysis. A Grand Chamber ruling of 2009 established that it was unlawful to both convict a defendant for a tax offence and to sentence him or her to pay a tax surcharge in relation to the same criminal activity. ${ }^{39}$ Doing so was not compatible with the 'ne bis in idem' principle, which means that a defendant should not be convicted twice for the same criminal activity. Accordingly, the Swedish Supreme Court later concluded that all persons who had been convicted in such cases subsequent to the Grand Chamber's ruling had the right to request a reopening of their case. ${ }^{40}$ The Swedish courts received hundreds of such applications. Many of these applications (167, of which $81 \%$ were approved) were included in the material examined by this study, but because they reflect a one-off and exceptional change in an issue of law that heavily increased the approval rate, they have not been analysed further.

Six other cases were also excluded, since they had been classified as confidential and would therefore have required a confidentiality assessment, of which one, a 'ne bis in idem' case, had been approved after post-conviction review. Applications that had been

39 The Grand Chamber of the European Court of Human Rights, Zolotukhin v. Russia, appl. no. 14939/03, 21.04.2009.

$40 \quad$ NJA 2013 p. 746. 
rejected on the grounds that they were not eligible for review were also excluded; these include, for example, duplicate applications and applications regarding convictions that had not yet become legally binding.

\subsection{Coding Procedure}

The cases were examined by means of a quantitative content analysis, which is a method used to quantify data sources that are originally of a qualitative nature. ${ }^{41}$ The method constitutes a systematic procedure for reviewing documents by coding and classifying the contents of the documents into predetermined categories. The use of content analysis in relation to the texts in the study's case files made it possible to describe typical patterns and characteristics of these cases. ${ }^{42} \mathrm{~A}$ coding scheme was developed and tested in a pilot study with the purpose of obtaining as much valuable information as possible from the cases examined. In this way, the characteristics of each stage in the post-conviction review process, from application to a possible exoneration, were categorised and numerically counted.

The contents of the case files were sorted into following categories: (1) the type of crime (the criminal act/s in focus in the application), (2) the court that issued the previous judgment (the Supreme Court, an appeal court, a district court), (3) the court deciding on the application (the Supreme Court, an appeal court), (4) characteristics of the application (application concerns issues of fact or issues of law, (5) the legal grounds invoked as a basis for the application (new evidence or new circumstances, unlawful administration of justice, criminal conduct or misconduct, false evidence or false statement, conflict of interest) $)^{43}$, (6) the applicant (convicted person, Prosecutor General, other), (7) whether the applicant was assisted by legal counsel, (8) decision (rejection or approval), (9) time markers (date of conviction, date of filed application, date of decision).

${ }^{41} \quad$ Boréus and Bergström, Textens mening och makt. Metodbok $i$ samhällsvetenskaplig text- och diskursanalys (Studentlitteratur 2012).

42 Prior, Using documents in social research. Introducing qualitative methods (Sage 2003).

43 According to the Code of Judicial Procedure, chapter 58 section 2, the invoked grounds should refer to information that would have affected the outcome of the judgment if the information was known at the time of the trial. In short, new evidence or new circumstances refers to the situation when specific evidence or more general, but still significant, circumstances has come to light; unlawful administration of justice is when the criminal proceeding has been executed in an unlawful manner; criminal conduct or misconduct refers to violations by a member of the court; false evidence or false statement is when a false evidence has made an impact on the judgment or when a witness has given a false testimony; conflict of interest is when a member of the court is considered to be unreliable and unable to make a fair decision due to competing interests. 


\section{Results}

\subsection{Outline}

The results section illustrates how wrongful conviction claims were dealt with by the criminal justice system in 2015. The presentation of data is divided into two sections. First, 216 applications involving wrongful conviction claims are described in order to illustrate the general patterns found among the criminal cases passing through the post-conviction review process, from application to possible exoneration. There then follows a more narrow description, with a specific focus on the characteristics of approved applications and the outcomes of reopened cases.

\subsection{Decisions on Wrongful Conviction Claims Over a One-Year Period}

Between the beginning of January and the end of December 2015, the Swedish courts issued decisions on 216 applications relating to wrongful conviction claims in which the applicant requested that a criminal case should be reopened. Of these, 209 applications were rejected and seven applications were approved. This represents a $3 \%$ approval rate. Table 1 illustrates which courts issued these decisions.

Table 1. Court deciding on applications

\begin{tabular}{lll}
\hline Courts & $\begin{array}{l}\text { Decided } \\
\text { applications }\end{array}$ & $\begin{array}{l}\text { Approved } \\
\text { applications }\end{array}$ \\
\hline Supreme Court & 170 & 2 \\
Appeal Courts (6) & 46 & 5 \\
$\quad$ Svea Hovrätt & 27 & 2 \\
Göta Hovrätt & 8 & 0 \\
Hovrätten för Skåne och Blekinge & 6 & 1 \\
Hovrätten Västra Sverige & 4 & 1 \\
Hovrätten Nedre Norrland & 1 & 1 \\
\hline Total & 216 & 7 \\
\hline
\end{tabular}

Most applications related to a conviction from one of the appeal courts. As a consequence, it was the Supreme Court that issued a decision on most of the applications (79\%). The courts are not required to give reasons for their decisions in any detail, and normally they merely provide the applicant with a few standard lines which states that the applicant did not present any relevant circumstances. As regards the characteristics of the applications, 110 applications were concerned with issues of fact. Of these, only one was approved $(0.9 \%)$. In contrast, 55 applications were concerned with issues of law. Of 
these, six applications were approved (11\%). In 51 applications it was unclear whether the application was concerned with an issue of fact or an issue of law. The applications were often submitted by the convicted person (95\%), either alone (73\%) or with the assistance of a legal counsel (27\%). In one case, the application for the case to be reopened was filed by a prosecutor, and in three cases the application was filed by the Prosecutor General. The convicted offender was male in $82 \%$ of the cases.

A total of 174 different legal grounds were presented in the applications - an applicant can include several grounds in the same application. Thirty-nine of the applications invoked two or three different grounds. As is illustrated in Table 2, the legal grounds most frequently cited for requesting the reopening of a criminal case were new evidence or new circumstances, followed by unlawful administration of justice. A conflict of interest was only cited as a legal ground in eight applications. It is important to note that the legal grounds for requesting a reopening were not always stated in the application. In 81 applications, the grounds were either not formulated at all or they were very unclear. This was common when the convicted person had filed the application alone, whereas the legal grounds for the application were expressed in a more concrete manner when the convicted person was assisted by a legal representative.

Table 2. Frequency of legal grounds invoked in applications

\begin{tabular}{lcc}
\hline Legal grounds & Frequency & Approved applications \\
\hline & & 2 \\
New evidence, new circumstances & 61 & 4 \\
Unlawful administration of justice & 53 & 0 \\
Criminal conduct, misconduct & 25 & 1 \\
False evidence, false statement & 27 & 0 \\
Conflict of interest & 8 & 7 \\
\hline Total & 174 & 0
\end{tabular}

Many applicants filed multiple applications, either in relation to the same conviction or in relation to a number of different convictions. ${ }^{44}$ Of the decisions issued in 2015,13 applicants had filed two applications, eight had filed three to four applications, one applicant had filed six applications and another had filed 12 applications. Altogether, this means that 70 of the applications in the data set have been filed by a total of 23 convicted persons. It is likely that some of these persons had filed applications in previous years. As this is not always stated in the case files, however, the exact number of previous applica-

44 Multiple applications are not to be confused with duplicate applications, which are identical versions of a previous application. Duplicate applications are automatically rejected by the court and are therefore not included in the study data. 
tions is unknown. For the purpose of this article, whose focus is directed at applications and how they are handled within the post-conviction review process, and not primarily at the applicants per se, no action has been taken to examine this issue further.

In total, 229 types of crime are represented in the 216 applications. Table 3 presents a list of the types of crime found in the material. An application may relate to a conviction for several types of crime, but the majority of applications included one to two offence types. The majority of the applications concerned a conviction for assault (32 applications), but tax offences and false accounting offences (29) were also common in the applications, even after the exclusion of the 'ne bis in idem' cases. Fraud was the next most common crime (15 applications), followed by murder, unlawful threats and road traffic offences (13 applications for each of these crime categories).

Table 3. Frequency of different offence types in applications and number of approved applications

\begin{tabular}{|c|c|c|}
\hline Offence types & $\begin{array}{l}\text { requency of offence types } \\
\text { applications }\end{array}$ & $\begin{array}{l}\text { Approved } \\
\text { applications }\end{array}$ \\
\hline Assault & 32 & 1 \\
\hline Tax offences and false accounting offences & 29 & 1 \\
\hline Fraud & 15 & 0 \\
\hline Murder & 13 & 0 \\
\hline Unlawful threat & 13 & 0 \\
\hline Road traffic offences & 13 & 2 \\
\hline Drug offences, incl. attempt & 9 & 0 \\
\hline Driving under the influence of narcotics/alcohol & 8 & 2 \\
\hline Rape, incl. child rape & 7 & 0 \\
\hline Illegal drug trade & 5 & 0 \\
\hline Molestation & 5 & 0 \\
\hline Disloyalty to principal & 5 & 0 \\
\hline False incrimination & 5 & 0 \\
\hline Attempted murder & 4 & 0 \\
\hline Attempted manslaughter & 4 & 0 \\
\hline Threat against a public servant & 4 & 0 \\
\hline Theft & 4 & 0 \\
\hline Defamation & 4 & 0 \\
\hline Gross violation of a woman's integrity & 4 & 0 \\
\hline Cruelty to animals / offences against Welfare Act & 3 & 0 \\
\hline Misconduct & 3 & 0 \\
\hline Stalking & 3 & 0 \\
\hline Criminal mischief & 3 & 0 \\
\hline Illegal alcohol trade & 2 & 0 \\
\hline Customs offences & 2 & 0 \\
\hline Sexual molestation & 2 & 0 \\
\hline Violation of a restraining order & 2 & 0 \\
\hline Weapons offences & 2 & 0 \\
\hline Dishonest conduct & 2 & 0 \\
\hline Attempted assault & 1 & 0 \\
\hline Violence against a public servant & 1 & 0 \\
\hline
\end{tabular}


Sara Hellqvist

Unlawful possession of weapons

Hunting offences

Hit-and-run

Robbery

Arson

Usury

Offences against the Knives Act

Attempted criminal mischief

Involuntary manslaughter

Petty theft

Embezzlement

Illegal alcohol sales

Data breach

Obstructing the course of justice

Other (e.g. forfeiture of property, the application is

concerned with a dismissal of appeal)

\begin{tabular}{ll}
1 & 0 \\
1 & 0 \\
1 & 0 \\
1 & 0 \\
1 & 0 \\
1 & 0 \\
1 & 0 \\
1 & 0 \\
1 & 1 \\
1 & 0 \\
1 & 0 \\
1 & 0 \\
1 & 0 \\
1 & 0 \\
& \\
6 & 0 \\
\hline 229 & 7 \\
\hline
\end{tabular}

$\frac{\text { Total }}{\text { Note. } \mathrm{N}=216 \text { applications. }}$

Table 4 shows that prison was the most common sanction that had been imposed in the criminal cases referred to in the filed applications (92), followed by fines (22) and committal to forensic psychiatric care (14). Unfortunately, information about the sentences that the offences had resulted in is missing in 59 cases. The applications were often related to criminal cases in which the conviction had been issued in the last few years, but the material also includes a number of older convictions. The oldest applications concerned a conviction issued in 1987 (robbery), 1991 (murder) and 1993 (rape). The mean processing time for applications to result in a court decision was 146 days. However, there is a substantial degree of variation in this regard. For example, decisions on two of the applications had been made after one day (one application filed by a man who had been sentenced to prison for gross violation of a woman's integrity, and one application relating to a speeding violation, both of which were rejected) whereas the decision on another application was made 771 days after the application had been filed (an application relating to a road traffic offence, which was also rejected).

Table 4. Sentences imposed in criminal cases in filed applications

\begin{tabular}{lcc}
\hline Sentences & Frequency & Approved applications \\
\hline & & 2 \\
Prison & 92 & 2 \\
Fine & 22 & 0 \\
Psychiatric care & 14 & 0 \\
Conditional sentence with community service & 9 & 1 \\
Conditional sentence with fine & 8 & 1 \\
Probation & 5 & 2
\end{tabular}




\begin{tabular}{lcl} 
Probation with community service & 2 & 1 \\
Community service & 2 & 0 \\
\hline Total & 157 & 6 \\
\hline
\end{tabular}

Note. $\mathrm{N}=216$ applications. Missing $=59$.

It was noted that the vast majority of the applications included in the material were filed in the interest of the convicted person, but three applications were to the detriment of the defendant. They all concerned suspected murder cases in which the defendant had been acquitted at the original trial. Two of the applications had been filed by relatives of a deceased victim while the third had been filed by the Prosecutor General, but none of these cases was reopened.

\subsection{The Characteristics and Outcomes of Reopened Criminal Cases}

When all 216 applications on which the courts issued a decision in 2015 are considered, seven applications, relating to seven convicted persons, were approved: two cases of driving under the influence of narcotics, one assault case, two cases of road traffic offences, one case relating to tax offences and one case of involuntary manslaughter. This represents a $3 \%$ approval rate. Four convicted persons who had requested a review of their case had their applications approved. The other three approved applications had been filed by a prosecutor or the Prosecutor General. In five of the reopened cases, the charges against the defendant were dropped immediately, either as a result of an unlawful administration of justice or of false evidence. The other two reopened cases were referred back to the lower courts for retrial. The charges were dismissed in one of these cases whereas the judicial outcome was unsettled in the other case at the time of writing. Only one of these cases related to an issue of fact where it was claimed that the defendant was not the perpetrator (a road traffic offence where the convicted person claimed he had not been the man in the vehicle but that another man had pretended to be him). If the focus is limited to approved applications only concerned with issues of fact, the approval rate decreases to $0.9 \%$ ( 1 out of 110 ), whereas the approval rate increases to $11 \%$ if the focus is instead limited to approved applications concerned with issues of law (6 out of 55). The characteristics of the seven reopened cases are presented in detail below.

Table 5a. Characteristics and outcomes of reopened criminal cases

\begin{tabular}{|c|c|c|c|c|}
\hline Cases & Type of crime & Sentence & ne b/w $\mathrm{w}^{\star}$ & Proc. time ${ }^{\star}$ \\
\hline 1 & Driving narcotics & Probation & 1668 & 201 \\
\hline 2 & Driving narcotics & Prison, 1 month & 800 & 202 \\
\hline 3 & Assault & Probation, com. service & 308 & 55 \\
\hline 4 & Road traffic offence & Fine & 1390 & missing \\
\hline 5 & Road traffic offence & Fine & 693 & 307 \\
\hline 6 & Tax offence & Prison, 1 year & 1992 & 80 \\
\hline
\end{tabular}


7 Inv. manslaughter Cond. sentence, fine 539 280

Note. ${ }^{\star}$ Time b/w: time between previous sentence and decision on application, in days.

${ }^{\star}$ Proc. time: processing time between filed application and decision on application, in days.

Table 5b. Characteristics and outcomes of reopened criminal cases, continued

\begin{tabular}{rlll}
\hline Cases & Applicant & Legal ground for reopening & Judicial outcome \\
\hline & & & \\
1 & Prosecutor General & Unlawful admin. of justice & Charges dismissed \\
2 & Prosecutor General & Unlawful admin. of justice & Charges dismissed \\
3 & Prosecutor & Unlawful admin. of justice & Sentence changed \\
4 & Convicted person & New evidence, circumstances & Charges dismissed \\
5 & Convicted person & Unlawful admin. of justice & Sentence changed \\
6 & Convicted person & New evidence, circumstances & Charges dismissed \\
7 & Convicted person & False evidence, statement & Unsettled \\
\hline
\end{tabular}

\subsubsection{Cases 1 and 2 - Two Instances of Driving Under the Influence of Narcotics}

In 2011 and 2013, the appeal court had convicted two men of driving under the influence of narcotics and sentenced them to probation and one month's imprisonment respectively. Two years later, the Prosecutor General filed an application for review to the Supreme Court stating that the two convictions had been wrongful as a result of an unlawful administration of justice. The convicted persons had been tested by the National Board of Forensic Medicine and tetrahydrocannabinol acid had been detected in their blood. However, whereas tetrahydrocannabinol is the principal psychoactive constituent in cannabis and is illegal, the acid constitutes a chemical by-product that is produced following the use of cannabis and is not in itself illegal. As a result of incorrect analyses, it could not be determined that the persons had been driving while under the influence of narcotics. The application was approved after six months and the charges against the defendants were immediately dismissed by the Supreme Court.

\subsubsection{Case 3 - Assault}

In 2014, a district court had convicted a male for assault. The man was already on probation and it was decided that the period of probation should be extended and should include his existing sentence. Due to a miscalculation regarding the time at which the period of probation was to end, it was found that the convicted man had been monitored for an excess period of six months. The prosecutor filed an application to the appeal court on behalf of the convicted man, invoking the ground of an unlawful administration of justice. The application was approved after two months and since the sentence had already 
been served, it was administratively changed and the excess six months of probation were subtracted from the original conviction.

\subsubsection{Cases 4 and 5 - Two Instances of Road Traffic Offences}

The first reopened case regarding a road traffic offence concerned a case from 2011. The police had issued a man with a summary fine for driving without a seatbelt, which had then been paid. However, the convicted man later claimed he had not been the man in the vehicle but that another man had pretended to be him. He petitioned the appeal court to reopen the case and the prosecutor supported the application. The exact dates are missing from this case file, but the appeal court approved the application and the man was immediately cleared on all charges. In the second reopened road traffic offence case, the police had issued a woman with a summary fine for violating the speed limit in 2013. Two years later the woman filed an application invoking the grounds of an unlawful administration of justice. She claimed that the road traffic signs had been mislabelled. In addition, other people had been cleared of charges for violating speed limits on that particular section of the road. Although the police opposed the application, it was approved by the appeal court after two months and the fine was cancelled.

\subsubsection{Case 6 - Tax Offences}

In 2010, the district court convicted a man for complicity in tax offences and he was sentenced to one year's imprisonment and to disqualification from engaging in commercial activities for three years. The convicted man requested that the case be reopened and invoked the ground of an unlawful administration of justice. In short, the company that had engaged in the alleged tax offences had actually been the subject of tax exemptions by the Swedish Tax Agency. The prosecutor consented to the application, which was approved by the appeal court after three months. Following a retrial, the tax offence charges against the defendant were dismissed.

\subsubsection{Case 7 - Involuntary Manslaughter}

A man was convicted for involuntary manslaughter by the district court in 2014. It was determined that he should pay compensation for pain and suffering, which he accepted. However, the convicted man later claimed that the relatives of the deceased victim had already received traffic insurance compensation, a circumstance of which he had not been cognisant at the time that he agreed to pay the compensation. In the filed application, the convicted man invoked false evidence as a legal ground for reopening the case. The 
convicted man requested that the sentence should be changed as a result of the circumstances described. The appeal court approved the application nine months later. The case was referred back to the district court and is currently under review.

\section{Discussion}

\subsection{Main Findings}

One way to improve our understanding of wrongful convictions is to focus on the process in which they are produced in a legalistic sense, i.e. the operation of the final legal safeguard. It is therefore crucial to have knowledge about how the post-conviction review process operates, the number of cases dealt with at each stage of the process and the characteristics of these cases: from application to possible exoneration. On this note, the present article constitutes an attempt to provide the beginnings of an empirical basis for an informed discussion of wrongful convictions. This has been achieved by providing an empirical overview of the Swedish post-conviction review process over a one-year period. The study describes how the Swedish criminal justice system has dealt with claims of wrongful convictions, from application to possible exoneration.

On the basis of 216 post-conviction review applications that resulted in a decision in 2015, the data tell the story of the typical wrongful conviction claimant during the period examined: this was a man sentenced to imprisonment by the appeal court for a violent offence. He formulated the application by himself, without legal representation, and claimed to be innocent of the offence. The legal grounds invoked in the application were either not sufficiently well clarified to be comprehensible or they had not been formulated at all. The application was filed a year after the initial verdict and it would take four months for the Supreme Court to reject the application. In contrast to this standard outcome there was a group of seven approved applications, all but one of which concerned legal technicalities. Four convicted persons had their charges dismissed and two had their sentence changed, whereas the case is yet unsettled for one convicted person. What conclusions can be drawn from these figures? Should the proportion of approved applications be considered low, and if so, is this a good thing or a bad thing? These questions are addressed below, in conjunction with a discussion of the need for more transparency in this particular area of the justice apparatus. 


\title{
4.2 Limitations and the Need for Transparency
}

Sweden is known for being characterised by bureaucratic transparency. While this is certainly the case in several respects, ${ }^{45}$ it has not been easy to collect information on the operation of the post-conviction review process. It is not that the information is unavailable; it is rather a case of the information being uncategorised, incoherent and disordered. ${ }^{46}$ For example, the case files are not categorised separately but together with other criminal cases and civil cases, which made it difficult for court archivists to collect the requested information. In addition, the case files are retained at the specific court that decided on the application, which meant that data had to be collected from seven sources (the Supreme Court and six appeal courts). Further, these courts employ different archiving procedures, e.g. with regard to how long the case files are stored at a particular court. Some courts retain case files for decades, whereas others send older cases to the Swedish National Archives on a more regular basis. Even if the case files were to be categorised in a more coherent way, only cases from the past nine years are searchable in the courts' digital archives. If one wished to conduct a longitudinal study, it would be necessary to visit each of the courts and to manually search for cases involving wrongful conviction claims among other type of cases. The limitations of the current study design are largely a result of these constraints, since they make it challenging to further extend the observation period. Moreover, the absence of accessible information is in itself problematic since statistics sometimes constitute the only means of obtaining insights into state affairs. ${ }^{47}$ As Andreas has put it:

\begin{abstract}
If something is not measured, it does not exist, if it is not counted, it does not count. If there is no data, it is not recognized, defined, prioritized, put on the agenda and debated. To measure something - or at least claiming to do so - is therefore to announce its existence and signal its importance and policy relevance. ${ }^{48}$
\end{abstract}

45 Administrative agencies that regularly provide statistics and crime-related information to citizens and researchers include Statistics Sweden, the Swedish National Council for Crime Prevention and the Swedish National Courts Administration.

46 The descriptions of the courts' archiving procedures are based on my correspondence with managers and archivists at the Swedish National Courts Administration, the appeal courts and the Supreme Court.

47 Von Hofer, Kriminalstatistik, makt och kontroll in Kontrollens variationer, eds. Pettersson and Pettersson (Studentlitteratur 2012) pp. 275-290.

48 Andreas, Number games: (Mis)measuring illicit flows and policy effectiveness Paper prepared for the International Studies Association San Francisco, March 26-29 (2008) Retrieved from http:// www.watsoninstitute.org/pubs_news/ISA_andreas.pdf (last accessed 31 January 2018). 
It would be reasonable for one of the administrative agencies to maintain an up-todate empirical basis for discussion, analysis and decision-making in this area, as is the case in relation to other parts of the criminal justice system..$^{49}$ From a research perspective, this kind of starting point would make it possible to employ much more fruitful study designs. Clearly, the theoretical understanding of this phenomenon could be advanced if it was possible to adopt a longitudinal approach and to study wrongful conviction claims and exonerations over a longer period of time.

For example, there have been incidents of rape case exonerations, in which the individuals in question had been convicted during the 1990s but were not exonerated until several years later, having filed several applications during this time. ${ }^{50}$ With more data, it would be possible to examine 'trends' in such types of potential wrongful convictions in detail. These could also be related to the contemporary crime policy discourse, looking, for example, at the emergence of the crime victim as a significant actor on the criminal justice arena.

\subsection{Moving Beyond the Needle in the Haystack}

It would be difficult to imagine a society governed by rule of law that lacked this final legal safeguard. ${ }^{51}$ Based on the view that no criminal justice system can be made foolproof, a certain number of overturned convictions can be considered necessary to illustrate that the system is functioning as it should. ${ }^{52}$ As a result, the way the post-conviction review process operates has implications for the criminal justice system's claims to legitimacy. ${ }^{53}$ From this perspective, however, it is difficult to establish what would constitute a reasonable level of exonerations. Thus, any interpretation of the approval rate will be ambiguous. Too many reopened cases could give cause for concern. While this could be seen as the result of a self-correcting justice system aware of its own flaws, others could take a high approval rate to be a sign of an unreliable justice system that was producing a large number of errors. Wrongful convictions are not currently considered a social problem in Sweden. Based solely on the approval rate found in the data examined in this study, this is perhaps quite reasonable. Only four persons were exonerated in 2015, in the sense that their convictions were overturned and they were acquitted in relation to the charges on

49 For example, reported offences, processed offences and court convictions are registered by the Swedish National Council for Crime Prevention. Court statistics are also published by the Swedish National Courts Administration.

50 See, for instance, the Supreme Court case number Ö 890-00; Ö 920-04; Ö 1459-12.

51 See Cars 1959.

$52 \quad$ See Leo 2016 pp. 82-106; see Stratton 2014 pp. 1-17.

53 See Ekelöf and Edelstam 2008; Naughton, The innocent and the criminal justice system. A sociological analysis of miscarriages of justice (Palgrave Macmillan 2013). 
which the conviction had been based. At the same time, it may be naive to interpret these figures as constituting the true proportion of wrongful convictions in Sweden without further consideration.

This raises the question of whether a small number of exoneration cases indicate that the criminal justice system is reliable or rather shows an unwillingness to examine potential flaws. On the one hand, wrongful convictions are conceived as constituting exceptional events and as being 'needles in a haystack. ${ }^{54}$ On this view, a small number of exonerations is evidence of a reliable system that rarely produces wrongful convictions but that, at the same time, takes responsibility in those exceptional cases when this nonetheless happens. ${ }^{55}$ On the other hand, we have the 'iceberg' metaphor, whereby a small number of exonerations is instead viewed as an indication of structural limitations in the provision of assistance to wrongful conviction claimants and of the existence of strict post-conviction rules that prevent applicants from obtaining approval for wrongful conviction claims. ${ }^{56}$ According to this line of thinking, the few exoneration cases that are identified represent the tip of an iceberg that is comprised of a larger number of undetected wrongful convictions. ${ }^{57}$ This is not to suggest that there is a mountain of undetected wrongful convictions in Sweden. However, it is crucial to shed light on some of the settings for the review procedure.

Besides the post-conviction review process not being empirically documented and systematically evaluated as an integrated part of the administrative agencies' activities, the regulations governing this process can be criticised in two main respects, which are related to one another: (1) the legal criteria for approving applications are constructed very narrowly, and (2) few applicants have access to legal support in order to collect and present valid information that falls within these strict legal criteria. Accordingly, applications submitted by convicted persons are seldom approved by the courts. The findings of this study show that the grounds for the application were either not formulated at all or were very unclear in 81 of the 216 applications. Evidently, these applicants found it difficult to provide the kind of information that is required by the existing regulations. Some applicants did have legal assistance, however, but this was either paid for by the applicants themselves or their counsel worked for free.

54 Medwed, The zeal deal: Prosecutorial resistance to post-conviction claims of innocence, 84 Boston University Law Review (2004) pp. 125-184.

55 Raymond, The problem with innocence, 49 Cleveland State Law Review (2001) pp. 449-465.

56 Acker, Taking stock of innocence: Movements, mountains, and wrongful convictions, 33 Journal of Contemporary Criminal Justice (2016) pp. 8-25; Dongois, Wrongful conviction in France. The limits of 'pourvoi en revision' in Wrongful Conviction. International Perspectives on Miscarriages of Justice, eds. Huff and Killias (Temple University Press 2008) pp. 249-262; Naughton, Claims of innocence. An introduction to wrongful convictions and how they might be challenged (University of Bristol 2012).

$57 \quad$ See Huff et al., 1986 pp. 518-544; see Stratton 2014 pp. 1-17. 
Drawing an analogy between the iceberg metaphor and this observation, other studies have shown that it is likely that the detected wrongful convictions may not be representative of the group of wrongful convictions as a whole..$^{58}$ Instead, access to justice may be an outcome of the resources that are assigned to a case, which is in turn dependent on the convicted person's socioeconomic characteristics, such as financial resources, level of education and language proficiency. ${ }^{59}$ Moreover, the Chief Justice of the Supreme Court has commented that the fact that the majority of the applications are dealt with by justices of the Supreme Court ( $79 \%$ in this sample 1 ) is problematic. ${ }^{60}$ The justices' main task is to formulate judicial precedents and they may not be suitable for evaluating evidence in these types of cases, which are, in addition, resource-intensive. This is relevant considering that a majority of the applications concerned issues of fact cases. In line with this, the court's lack of experience in handling wrongful conviction claims was one of the arguments in favour of creating an independent review commission in Norway, Canada and the United Kingdom. ${ }^{61}$

From this perspective, both the applicants and the courts have their hands tied. Evidently, the courts are only assessing the applications according to the existing legal framework It may also be the case that the approval rate would be unaffected even with a lower approval threshold and/or with the provision of legal assistance to applicants. However, the issue is not concerned with achieving a certain amount of exonerations, but to offer convicted persons a fair chance to exercise the right to request post-conviction review of a criminal case. It is essential that legal rights and remedies are real and not merely symbolic. ${ }^{62}$

\subsection{Closing Remarks}

The wrongful conviction scholarship is about improving the extent to which the criminal justice system safeguards the rule of law. To date, there are limitations to our understanding of wrongful convictions in Sweden, of how alleged errors of justice are dealt with and of the possibilities for having convictions overturned. As is true for all Nordic countries, there are a number of legal safeguards that serve to protect the rights of defendants, but we know little about this particular part of the criminal justice system in Sweden. Despite

\footnotetext{
$58 \quad$ See Gross 2013 pp. 45-59.

59 See Curran and Noone 2008 pp. 195-229.

60 Veckans Juridik (2015, November 11). Stefan Lindskog: 'Resningsärendena hör inte hemma i Högsta domstolen'. Retrieved from https:/www.bgplay.se/video/stefan-lindskogresningsarendena-hor-inte-hemma-i-hogsta-domstolen (last accessed 31 January 2018).

${ }_{61}$ See Nobles and Schiff 2001 pp. 280-299; see Stridbeck and Magnussen 2011-2012 pp. 267-283.

62 Garth and Cappelletti, Access to justice: The newest wave in the worldwide movement to make rights effective, Paper 1142 Articles by Maurer Faculty (1978) pp. 180-292.
} 
the important role played by the post-conviction review process, it remains something of a blind spot for the critical scholarship focused on the criminal justice system. On the basis of the findings presented above, it might reasonably be argued that having empirical information constitutes a good point of departure for the initiation of a discussion of this complex phenomenon. It is recommended that the Swedish criminal justice system should implement systematic and continuous procedures to identify problems in the operation of this process, such as the one employed in the present study. This is a necessary first step to providing a basis for deciding whether Sweden needs to introduce additional precautionary measures, like the creation of a specific institution to address wrongful convictions such as those found in Norway, Canada and the United Kingdom. 